\title{
Protection of adenovirus from neutralizing antibody by cationic PEG derivative ionically linked to adenovirus
}

This article was published in the following Dove Press journal:

International Journal of Nanomedicine

23 February 2012

Number of times this article has been viewed

\section{Qin Zeng \\ Jianfeng Han \\ Dong Zhao \\ Tao Gong \\ Zhirong Zhang \\ Xun Sun}

Key Laboratory of Drug Targeting and Drug Delivery Systems, Ministry of Education, West China School of Pharmacy, Sichuan University, Chengdu, People's Republic of China

Correspondence: Xun Sun

West China School of Pharmacy, Sichuan University, No 17 Section 3 Southern

Renmin Road, Chengdu 61004I, People's

Republic of China

Tel/Fax +86 2885502307

Email xunsun22@gmail.com
Background: The generation of anti-adenovirus neutralizing antibody (NAb) in humans severely restricts the utilization of recombinant adenovirus serotype 5 (Ad5) vectors in gene therapy for a wide range of clinical trials. To overcome this limitation, we ionically complexed Ad5 with a newly synthesized copolymer, which we called APC, making an adenovirus shielded from NAb.

Methods: APC, a cationic polyethylene glycol derivative, was synthesized via two steps of ring-opening copolymerization of ethylene oxide and allyl glycidyl ether, followed by the addition of 2-mercaptoethylamine. The copolymer or the control PEI-2k was ionically complexed to anionic Ad5 in 5\% glucose, and in vitro transduction assays were carried out in coxsackievirus and adenovirus receptor-positive cells (A549) and coxsackievirus and adenovirus receptornegative cells (B16 and SKOV3). The physical properties and morphology of adenovirus alone or the complexes were investigated respectively by zeta potential, size distribution, and transmission electron microscopy image. Then cytotoxicity of APC was examined using 3-[4, 5-dimethylthiazol-2-yl]-2, 5-diphenyltetrazolium bromide assays. Finally, the ability of APC to protect adenovirus from NAb was evaluated by transfection assays after a neutralizing effect.

Results: APC was successfully synthesized and showed a low cytotoxicity. Positively charged Ad5/APC exhibited slightly increased diameter $(130.2 \pm 0.60 \mathrm{~nm})$ than naked Ad5 $(115.6 \pm 5.46 \mathrm{~nm})$ while Ad5/PEI-2k showed severe aggregation (1382 $\pm 79.9 \mathrm{~nm})$. Ad5/APC achieved a gene transfection level as high as Ad5/PEI-2k in A549 or B16 cells, and significantly higher than Ad5/PEI-2k in SKOV3 cells. Most importantly, after the exposure to the neutralizing antibody, naked Ad5 and Ad5/PEI-2k exhibited poor gene expression while Ad5/APC still showed significantly efficient gene expression.

Conclusion: Our results demonstrated that Ad5/APC complex offered good protection for Ad5 against NAb in vitro and suggested a potential strategy of resistance to NAb in vivo.

Keywords: adenovirus, cationic PEG derivative, anti-adenovirus neutralizing antibody

\section{Introduction}

Recombinant adenovirus vectors (Adv) have been under extensive exploration as gene delivery systems for gene therapy or vaccines. ${ }^{1-3}$ As reported in 2009 , viral vectors for gene therapy accounted for $66 \%$ of all those in clinical trials, approximately $25 \%$ of which were Adv-based vectors. ${ }^{4}$ In particular, adenovirus-mediated p53 gene therapy has been proven effective in clinical trials by intratumoral administration for cancer treatment. ${ }^{5,6}$ Recently, Adv-based research has entered the new fields of nanomedicine and nanodiagnostics. ${ }^{7}$ The broad application based on Adv originated from their special advantages over other viral and nonviral vectors, primarily containing their 
high efficiency in transduction and transgenic expression and low pathogenicity.

Unfortunately, capsid proteins of Adv are immunogenic; in animal and human studies anti-adenovirus neutralizing antibodies (NAbs) were elicited within one week after initial exposure to Adv. ${ }^{8,9}$ The titer of NAb increased to a peak within 4 weeks. ${ }^{10}$ When readministrated, NAb recognized and neutralized Adv before internalizing into targeted cells, leading to an inefficient transduction. Moreover, pre-existing anti-Adv neutralizing antibodies in a large population of people worldwide, especially anti-Ad5 antibodies, is a barrier for Adv-mediated clinical applications. ${ }^{1-13}$ In addition, Adv are limited to local administration due to substantial liver tropism and subsequent severe hepatotoxicity after systemic administration. ${ }^{14}$ Therefore, none of the Adv-mediated gene therapy drugs has been FDA-approved so far.

Over the past decade, the most frequently used strategies to solve this problem have been hybrid vectors that combine viral and nonviral vectors. Nonviral vectors are nonimmunogenic, thus a liposome envelope or a polymer coating shields Adv and thereby reduces the immunogenicity or prevents recognition by the immune system or NAb. Adv can be divided into two groups: those that are covalently chemically conjugated and those that are physically self-assembled, each of which has their drawbacks. A typical example of chemical conjugation is pegylation, which has been confirmed as an efficient technique in several studies. ${ }^{15-19}$ However, studies have shown that chemical conjugation reduced infection activity of Adv, associated with steric hindrance from flexible polyethylene glycol (PEG) chains, resulting in a decreased gene transduction and transgenic expression. ${ }^{16,20,21}$ This can be partially compensated for by a targeted ligand covalently conjugated to the PEG (ligand-PEG-Adv). ${ }^{22,23}$ Moreover, chemical conjugation showed protection of Adv in a titer-related way, but still failed in complete avoidance of the immune response or a negligible influence by NAb. The techniques of pegylation need to be further optimized, including the covalent site on Adv, PEG size and density, and reaction conditions. ${ }^{15,21,24,25}$ Alternatively, Adv can be modified by physical self-assembly, which is easier to handle and avoids potential inactivity of Adv during chemical synthesis. Cationic polymers (polyethylenimine [PEI], lipofectamine, and chitosan) have been widely investigated in enhancing gene transduction abilities, but most of the complexes showed weak evasion from NAb. ${ }^{26-30}$ Moreover, aggregation of Adv induced by cationic polymers suggested unstable complexation ${ }^{29}$ and simultaneous toxicity associated with cationic polymers also limited clinical applications. ${ }^{31}$
For the efficient delivery of plasmid DNA, it has been reported that PEG covalently conjugated to cationic polymers such as PEG-poly-L-lysine (PLL), ${ }^{32}$ PEG-PEI, ${ }^{33}$ and PEG-chitosan ${ }^{34}$ could form stable and low toxic nonviral vectors. Therefore, we hypothesized that a PEG grafted cationic polymer can improve the stability of Adv-cationic polymer complexes and that linear PEG extending outside can protect $\mathrm{Ad} 5$ from NAb as well as achieve effective transgenic expression.

In our study, cationic PEG derivatives (APC), a linear PEG with one side blocked by amine pendants, was synthesized to immobilize onto negatively charged capsid proteins of Ad5 for evading NAb (Figure 1). We hypothesized that amines play a bridge-like effect, linking a linear PEG and Ad5. Simultaneously, the linear PEG extends outside, protecting Ad5 from interaction with $\mathrm{NAb}$ or cells in blood. Then replicate-incompetent Ad5 expressing $\beta$-gal (Ad5LacZ) were complexed with APC or the control PEI-2k in a serial ratio. Next, in vitro transfection assays were carried out in coxsackievirus and adenovirus receptor (CAR)positive cells (A54935) and CAR-negative cells (B16, ${ }^{36}$ $\mathrm{SKOV}^{37}$ ). Finally, the ability of APC to protect Ad5 from evading $\mathrm{NAb}$ was evaluated by in vitro neutralizing assays in A549 cells.

\section{Materials and methods Chemical reagents and biomaterials}

Branched PEI (2 kd), allyl glycidyl ether (AGE), and 3-[4, 5-dimethylthiazol-2-yl]-2, 5-diphenyltetrazolium bromide (MTT) were purchased from Sigma Chemical Co, (St Louis, MO). 2-mercaptoethylamine was obtained from Aladdin Chemistry Co, Ltd, (Shanghai, China). Ethylene oxide (EO) was obtained from Xinhua Institute of Active Material (Changzhou, Jiangsu, China). O-nitrohenyl- $\beta$-Dgalactopyranoside and cesium chloride (molecular biology grade) were obtained from Amersco (Solon, $\mathrm{OH}$ ).

\section{Cell lines}

E1-transformed human embryonic kidney cell line HEK 293 was purchased from ATCC (CRL1573) and cultured in Dulbecco's modified Eagle's medium (GIBCO-BRL, Grand Island, NY) supplemented with $10 \%$ fetal bovine serum (FBS), 100 units $/ \mathrm{mL}$ penicillin, and $100 \mu \mathrm{g} / \mathrm{mL}$ streptomycin, incubated at $37^{\circ} \mathrm{C}$ in a $95 \%$ humidified atmosphere containing $5 \% \mathrm{CO}_{2}$. Non-small cell lung carcinoma cell line A549, murine melanoma cell line B16, and human ovarian cancer cell line SKOV3 were obtained from Chinese Academy of Sciences (Shanghai, China) and cultured in RPMI-1640 (GIBCO-BRL, Grand Island, NY) complemented with 10\% 


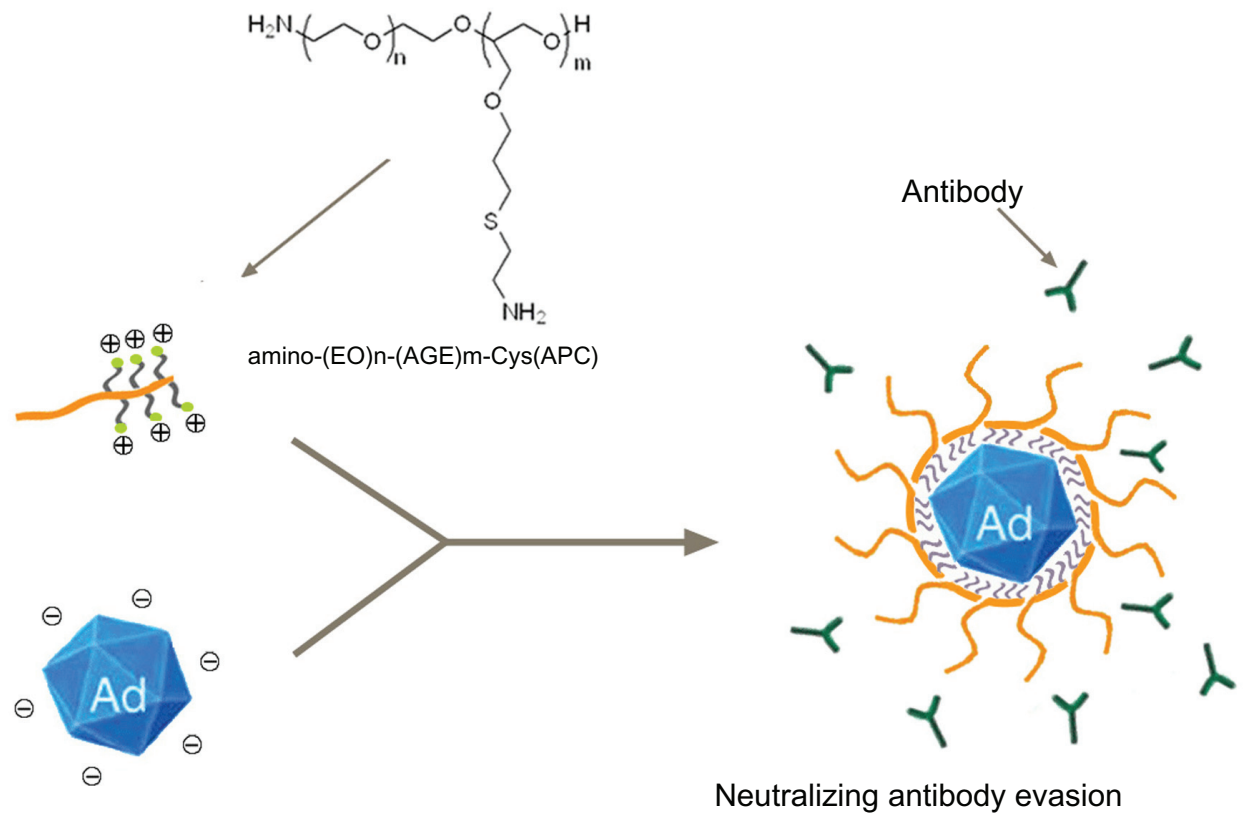

Figure I Schematic representation of adenovirus complexed with cationic PEG derivative (Ad5/APC) for evading anti-adenovirus neutralizing antibody (NAb). Abbreviations: EO, ethylene oxide; AGE, allyl glycidyl ether; APC, cationic PEG derivative; Ad5, adenovirus vectors type 5.

FBS, 100 units/mL penicillin, and $100 \mu \mathrm{g} / \mathrm{mL}$ streptomycin, cultured in the same conditions as above.

\section{Adenovirus preparation}

E1/E3-deleted recombinant type 5 adenovirus vectors encoding $\mathrm{LacZ}$ reporter gene and expressing $\beta$-galactosidase (Ad5-LacZ) were purchased from the Vector Gene Technology Company Limited (Beijing, China). Replication-deficient Ad5 vectors were amplified in HEK 293 cells and purified from the cells' lysate through two steps of $\mathrm{CsCl}$ gradients ultracentrifugation. Next, the underlayer of viral band was desalted by dialysis at $4^{\circ} \mathrm{C}$ for 4 hours against dialysis buffer (10 mM Tris pH 8.0, $2 \mathrm{mM} \mathrm{MgCl}_{2}, 5 \%$ sucrose) with a cellulose ester membrane of molecular weight (MW) cut off $25 \mathrm{kd}$ before being stored in aliquots at $-80^{\circ} \mathrm{C}$ until use. Finally, the titer of virus stock was evaluated as $2.5 \times 10^{11}$ plaque-forming units per $\mathrm{mL}(\mathrm{pfu} / \mathrm{mL})$ by established plaqueforming assay or $2.0 \times 10^{12}$ viral particles per $\mathrm{mL}(\mathrm{vps} / \mathrm{mL})$ by measurements of ultraviolet absorption at $260 \mathrm{~nm}$ (OD260). Multiplicity of infection (MOI) value is defined as the ratio of total number of pfu per number of cells. In our in vitro study, MOI was approximately equivalent to 40 .

\section{Synthesis of the copolymer (APC) \\ Protection of 2-aminoethanol with tert- butoxycarbonyl (Boc) group}

Boc group was conjugated to 2-amino ethanol to prevent amine from oxidation in the following process.
Typically, a solution of sodium hydroxide $(10.03 \mathrm{~g})$ in $50 \mathrm{~mL}$ distilled water was added to a solution of $\beta$-aminoethanol $(7.37 \mathrm{~g})$ in $25 \mathrm{~mL}$ methanol. While stirring in an ice bath, $(\mathrm{Boc})_{2} \mathrm{O}(32.72 \mathrm{~g})$ in $25 \mathrm{~mL}$ methanol was added dropwise to the mixture. After another 24 hours stirring at room temperature, the reaction mixture was filtrated and the filtrate was extracted three times by acetoacetate, and then washed with distilled water until it became neutral, followed by wash again with saturated salt solution. Next, the mixture was dried by waterless sodium sulfate, and the solvent was removed by rotary evaporation under reduced pressure. Finally a viscous product was obtained, namely Boc-aminoethanol.

\section{Boc- $(E O)_{n} /(A G E)_{m}$ copolymerization}

Boc-(EO) $)_{\mathrm{n}} /(\mathrm{AGE})_{\mathrm{m}}$ was copolymerized by two steps of ringopening of EO firstly and AGE. Typically, Boc-aminoethanol $(0.88 \mathrm{~g})$ as the initiator, after dehydration for 1 hour at $90^{\circ} \mathrm{C}$ through oil pump reduced pressure, was dissolved in nonaqueous dioxane. While stirring at $60^{\circ} \mathrm{C}$, sodium cyanide $(60 \%$, $0.92 \mathrm{~g})$ was added, and nonaqueous EO $(100 \mathrm{~mL})$ purified by reforming was added dropwise to the mixture by a constant pressure funnel connected with a condensing tube $\left(4^{\circ} \mathrm{C}-8^{\circ} \mathrm{C}\right.$ recirculation water) and a drying tube filled with waterless calcium chloride to maintain an anhydrous reaction system. After EO recirculation came to an end, AGE (30.1 g) was added to the reaction mixture and stirred for another 2 days at $60^{\circ} \mathrm{C}$. Afterwards, water was added to stop the reaction, and $1 \mathrm{M}$ hydrochloric acid was used to adjust $\mathrm{pH}$ to neutral. 
The solvent was then removed by rotary evaporation under reduced pressure, and the residue was again dissolved in dichloromethane, dried by waterless sodium sulfate, filtrated, centrifuged, and the supernatant was condensed by rotary evaporation under reduced pressure. Finally, after further purification by repeated precipitation of diethyl ether three times, a yellowish product resulted, namely Boc-(EO) $)_{\mathrm{n}} /(\mathrm{AGE})$ ${ }_{\mathrm{m}}$, where $n$ or $m$ is represented as the number of monomers.

Deprotection of Boc-(EO) $)_{\mathrm{n}} /(\mathrm{AGE})_{\mathrm{m}}$ Boc-(EO) $)_{\mathrm{n}} /(\mathrm{AGE})_{\mathrm{m}}$ was deprotected by trifluoroacetic acid. Briefly, Boc-(EO) $/(\mathrm{AGE})_{\mathrm{m}}(2.0 \mathrm{~g})$ copolymer was dissolved in $10 \mathrm{~mL}$ dichloromethane containing $40 \%$ trifluoroacetic acid (v/v), which was stirred at RT for 2 hours. After removal of the solvent by rotary evaporation under reduced pressure, the mixture was redissolved in methanol and dialyzed for 2 days against distilled water through cellulose $(3.5 \mathrm{kd})$. Finally, lyophilization of the solution gave a product, namely amino-(EO) $)_{\mathrm{n}} /(\mathrm{AGE})_{\mathrm{m}}$.

\section{Addition of 2-aminoethanethiol to amino-(EO) $)_{n}$ $(\mathrm{AGE})_{\mathrm{m}}-\mathrm{CYS}(\mathrm{APC})$}

Addition of 2-aminoethanethiol to the double bond of amino$(\mathrm{EO})_{\mathrm{n}} /(\mathrm{AGE})_{\mathrm{m}}$ was performed according to the protocol reported by Koyama et al. ${ }^{38}$ Briefly, amino-(EO) $/($ AGE) $(1.03 \mathrm{~g})$ was dissolved in methanol $(4 \mathrm{~mL})$, and was added dropwise to the solution of 2-aminoethanethiol hydrochloride $(3.01 \mathrm{~g})$ in methanol $(8 \mathrm{~mL})$. After stirring at room temperature for 2 days, the reaction mixture was evaporated to remove the methanol. The residual syrup was dialyzed against distilled water for 3 days though cellulose membrane (MW cut off 3.5 $\mathrm{kd})$. Lyophilization of the solution gave a yellowish product, namely amino-(EO) ${ }_{\mathrm{n}}(\mathrm{AGE})_{\mathrm{m}}$ - Cys (APC).

\section{Characterization of APC}

To confirm synthesis of the APC polymer, the ${ }^{1} \mathrm{H}-\mathrm{NMR}$ spectras of intermediates and the final product APC were recorded on liquid samples $\left(\mathrm{CD}_{3} \mathrm{CL}\right.$ or $\mathrm{D}_{2} \mathrm{O}$; Sigma-Aldrich) in a Varian UNITY INOVA400 NMR Spectrometer (Palo Alto, CA) at $400 \mathrm{MHz}$.

The MW of APC was estimated by gel permeation chromatography (GPC), calibrated with PEG using Shodex KB-803 column (Shoko Co, Tokyo, Japan), Waters 515 pump, and Waters 2410 Refractive Index Detector (Waters Corporation, Milford, MA). Briefly, APC was dissolved in ultrapure water at a concentration of $10 \mathrm{mg} / \mathrm{mL}$. Acetate buffer $0.5 \mathrm{M}$ (acetate-sodium acetate) was used as eluent with a flow rate of $0.5 \mathrm{~mL} / \mathrm{min}$.
To determine the content of amines per molar of APC or indirectly charge APC bearing, analysis of nitrogen, carbon, and hydrogen was performed using an elementary analysis instrument (CARLO ERBA 1106; Carlo, Milan, Italy) and the sulfur atom was measured using the oxygen flask combustion method. The sample was in a completely dry form.

\section{Preparation of Ad5 complexed cationic polymer}

Complexes of Ad5 and APC or PEI-2k were formed as follows. Initially, stock solutions of APC $(10 \mathrm{mg} / \mathrm{mL})$, PEI-2k (10 mg/mL) and 5\% glucose $(\mathrm{w} / \mathrm{v})$ in ultrapure water were respectively filtered through $0.22 \mu \mathrm{m}$ pore sized filters. Then a serial concentration of dilutions of APC and PEI-2k in 5\% glucose were respectively added dropwise to the isovolumic Ad5-LacZ dilution in 5\% glucose with fixed particles of Ad5. After gently pipetting several times, the samples were incubated at room temperature for 25 30 min to form complexes of Ad5/APC or Ad5/PEI-2k. Complexes were freshly prepared before use every time.

\section{In vitro transfection assays}

To determine the best ratio of naked Ad5 and polymers (APC or PEI-2k), in vitro transfection assays were carried out in CAR over-expressing A549 cells. Briefly, A549 cells were seeded in 24 wells tissue culture plate at a density of $1 \times 10^{5}$ cells per well for 24 hours. When the cells reached $80 \% \sim 90 \%$ confluence, Ad5/LacZ $\left(1.25 \times 10^{7}\right.$ pfu per well, $1 \times 10^{8}$ vps per well, MOI 40) were complexed with a serial dose of APC and PEI-2k (50, 150, 300, 450, 600, 750, $1000 \mathrm{ng}$ ) in $5 \%$ glucose. After staying at room temperature for $25 \sim 30 \mathrm{~min}, 50 \mu \mathrm{L}$ per well of complexes were applied to the cells in $200 \mu \mathrm{L}$ RPMI-1640 medium without serum. After incubation at $37^{\circ} \mathrm{C}$ for 4 hours, the medium was replaced by fresh RPMI-1640 complete medium. After 24 hours incubation, cells were washed by PBS and lyzed by cell lysis buffer. Next, $\beta$-galactosidae and total protein concentration were respectively quantified by colorimetry using o-nitrohenyl- $\beta$ D-galactopyranoside as the substrate and a BCA kit (Pierce, Rockford, IL). The transfection efficiency was represented as unit of $\beta$-galactosidase per milligram of total protein (u/mg protein).

After the optimal ratio of Ad5 and polymers were determined, in vitro transfection assays of naked Ad5 or complexes at the optimal ratio were also carried out in CAR negative cells (SKOV3 and B16) with the same processes as described above. 


\section{Cytotoxicity}

For cytotoxicity assays, A549, SKOV3, and B16 cells were seeded in 96 wells tissue culture plate $\left(1 \times 10^{4}\right.$ cells/ well) in RPMI-1640 complete medium. The background wells had no cells but RPMI-1640 complete medium. When cells achieved $80 \% \sim 90 \%$ confluence, $10 \mu \mathrm{L}$ per well of freshly prepared complexes of Ad5 $\left(2 \times 10^{7} \mathrm{vps} /\right.$ well, $2.5 \times 10^{6} \mathrm{pfu} /$ well), coated with a serial concentration of APC or PEI-2k dilutions respectively in $5 \%$ glucose were treated to the cells in $90 \mu \mathrm{L}$ RPMI-1640 medium without serum, with the final concentrations of copolymers as follows: $1,5,10,20 \mu \mathrm{g} / \mathrm{mL}$. The control and background wells were added to $10 \mu \mathrm{L}$ of $5 \%$ glucose in $90 \mu \mathrm{L}$ RPMI-1640 medium without serum. Each sample had five repeated wells. After maintaining for 4 hours, the medium were replaced by 200 $\mu \mathrm{L}$ of fresh RPMI-1640 medium containing 10\% FBS for a further 24 hours incubation, $20 \mu \mathrm{L}$ per well of MTT solution $(5 \mathrm{mg} / \mathrm{mL})$ was added to the plate and further maintained for 4 hours at $37^{\circ} \mathrm{C}$. Subsequently, the medium and MTT were carefully removed and replaced by $150 \mu \mathrm{L}$ dimethyl sulfoxide. After shaking at $37^{\circ} \mathrm{C}$ for $30 \mathrm{~min}$, the absorbance of each plate was read at $490 \mathrm{~nm}$ using varioskan@Flash instrument (Thermo Scientific, Waltham, MA). Relative cell viability was calculated by the formula as $\left(\mathrm{A}_{\text {sample }}-\mathrm{A}_{\text {blank }}\right) /\left(\mathrm{A}_{\text {control }}-\mathrm{A}_{\text {blank }}\right) \times 100 \%$.

\section{Size and zeta potential measurement of naked adenovirus and complexes}

The average diameter and zeta potential of naked Ad5 and complexes of Ad5/APC and Ad5/PEI-2k at the optimal ratio were respectively measured by dynamic light scattering and electrophoretic light scattering, using a photon correlation spectroscopy (Malvern Zetasizer Nano ZS90, Malvern Instruments Ltd, Worcestershire, UK) with a $50 \mathrm{mV}$ laser. Before measurement, $200 \mu \mathrm{L}$ of naked Ad5 or freshly prepared complexed samples of Ad5/PEI-2k, Ad5/APC containing $2 \times 10^{10} \mathrm{vps}$ of Ad5-LacZ were diluted to $1 \mathrm{~mL}$ with ultrapure water. Then the measurement was performed at $25^{\circ} \mathrm{C}$ and a fixed angle of 90 with 2 min of equilibrium time and automatic cycles of measurement determined by the instrument. Each measurement was carried out in triplicate.

\section{Morphological investigation by transmission electron microscopy (TEM)}

The morphology of Ad5 alone or complexes of Ad5/APC were observed with a transmission electron microscope (tecnaiG ${ }^{2} \mathrm{~F}-20, \mathrm{FEI}$, Eindhoven, Holland) at an accelerating voltage of $20 \mathrm{kV}$, using a negative stain technique. Briefly, 20 $\mu \mathrm{L}$ of naked Ad5 or freshly prepared complex (Ad5/APC) at optimal ratio containing $1 \times 10^{9}$ vps of Ad5 were respectively added on a copper grid and left for $10 \mathrm{~min}$, enabling a sufficient adsorption. Then the solution was removed with filter paper and replaced with $1 \%$ aqueous uranyl acetate, staining for $1 \mathrm{~min}$. After removal of the dye with filter paper and dryness at $37^{\circ} \mathrm{C}$, the samples were imaged by transmission electron microscopy.

\section{Evaluation of APC protecting Ad5 from NAb}

Primarily for preparation of antiserum from mice, C57BL/6 N mice (4 to 5 week old, male) were obtained from the Laboratory Animal Center of Sichuan University, and were housed under specific pathogen-free conditions for one week to acclimate. The animal experiments were approved by the Institutional Animal Care and Ethic Committee of Sichuan University. On day -28 , the mice were randomly divided into two groups - one group of mice was immunized by intramuscular injection in the right hind limb with $5 \times 10^{10}$ vps of recombinant adenovirus (Ad5-LacZ) in $50 \mu \mathrm{L}$ of $5 \%$ glucose per mouse, and the other group was intramuscularly administered 5\% glucose. On day -14 , this immunization was repeated. On day 0 , the blood was respectively collected from the orbits vein of the immunized and nonimmunized mice. The blood was coagulated at room temperature for $15 \mathrm{~min}$ and centrifuged (2000 rpm, $30 \mathrm{~min}$ ). Finally, the supernatant antiserum and blank serum was respectively collected, pooled, and stored at $-80^{\circ} \mathrm{C}$ before use.

In order to evaluate the ability of APC to protect Ad5 evading from $\mathrm{NAb}$, the antiserum or blank serum was complement inactivated at $56^{\circ} \mathrm{C}$ for $30 \mathrm{~min}$ in advance. Naked Ad5 $(50 \mu \mathrm{L})$, and complexes of Ad5/PEI-2k or Ad5/APC at the optimal ratio containing $1.25 \times 10^{7}$ pfu of Ad5-LacZ, were respectively incubated with $200 \mu \mathrm{L}$ of diluted antiserum or blank serum at $37^{\circ} \mathrm{C}$ for 1 hour, making a neutralizing effect and the final dilution of the serum was 1:50 and 1:250. Then $250 \mu \mathrm{L}$ per well of the mixture was respectively treated to A549 cells in 24 wells tissue culture plate, for which a confluence of $80 \% \sim 90 \%$ had been achieved. The following processes were the same as the in vitro transfection. According to comparison of gene expression efficiency among naked Ad5, complexes of Ad5/PEI-2k and Ad5/APC in A549 at the presence of antiserum or blank serum, the ability of APC protecting Ad5 evading NAb were relatively evaluated.

\section{Statistical analysis}

All the above assays were performed at least in triplicate. The data are shown as the mean \pm standard deviation (SD). 
Statistical analysis was carried out by Student's $t$-test. The value of $P<0.05$ was considered to be statistically significant.

\section{Results}

\section{Synthesis and characterization of APC}

APC was prepared by two steps of ring-opening copolymerization of EO and AGE, with Boc-aminoethanol as the initiator, followed by deportation of the Boc group and addition of 2-mercaptamine to the pendant of allyl groups. The main routes of synthesis are given in Figure 2. The synthesis of APC was confirmed by ${ }^{1} \mathrm{H}-\mathrm{NMR}$ as follows.

Firstly, on the spectra of Boc-aminoethanol, occurrence of peaks of $\delta\left(\mathrm{CH}_{3} \mathrm{CO}-\right)=1.448, \delta\left(-\mathrm{CH}_{2} \mathrm{OH}\right)=3.285$ indicated that Boc group had been successfully congjugated to the amine of aminoethanol. Then the polymerization of EO with Boc-aminoethanol as an initiator has been characterized by the typical peaks of $\delta\left(-\mathrm{O}-\mathrm{CH}_{2}-\mathrm{CH}_{2}-\mathrm{O}\right)=3.740 \sim 3.382$ and $\delta\left(-\mathrm{O}-\mathrm{CH}-\mathrm{CH}_{2}-\right)=3.803$. The following polymerization of $\mathrm{AGE}$ was confirmed by the double bond peak of $\delta\left(-\mathrm{CH}=\mathrm{CH}_{2}-\right)=5.867$ and $\delta\left(-\mathrm{CH}=\mathrm{CH}_{2}-\right)=5.216$. (The chemical shift of hydrogen atoms is shown in bold in this paragraph.) Next, deprotection of Boc group was achieved due to disappearance of the methyl peak of Boc group, and the spectra of final product, Amino-(EO) $/(\text { AGE })_{\mathrm{m}}$-Cys, showed no alkenyl peaks, demonstrating a complete addition.

The MW of APC was estimated to be 19571 Da by GPC with PEG as standard substance. Elemental analysis of APC showed that nitrogen took up $2.38 \%$, carbon $48.76 \%$, hydrogen $8.21 \%$, and sulfur $4.88 \%$. From the mass percentage of nitrogen and carbon together with the MW and molecular formula of APC, it can be calculated that $n$ was 36 and $\mathrm{m}$ was 288, respectively, indicating the number of monomers of EO and AGE. In the following, the linear PEG on APC was inferred to $12.6 \mathrm{kd}$ with 36 amines per molecular APC.

\section{Enhanced transgenic expression efficiency by adenovirus complexed with APC}

To evaluate the optimal ratio of polymer (APC, PEI-2k) and Ad5-LacZ, Ad5-LacZ $\left(1.25 \times 10^{7} \mathrm{pfu}\right)$ coated with a serial dose of PEI-2k or APC over the range from $50 \mathrm{ng}$ to $1000 \mathrm{ng}$ were transfected in CAR-rich A549 cells. As shown in Figure 3A, the peaks of the two curves, indicating the relation of gene transfection efficiency and polymer weight, revealed the optimal proportion of adenovirus and polymers (APC, PEI-2k), $1.25 \times 10^{7} \mathrm{pfu}$ of adenovirusLacZ corresponded to $600 \mathrm{ng}$ for both PEI-2k and APC $(P<0.05)$. Excitingly, APC-mediate Ad5 gene transfection at the optimal ratio achieved as efficiently as PEI-2k $(P>0.05)$. Both of the polymers enhanced gene expression of naked Ad5 by approximately 10 times. The results may suggest a CAR-independent transfection for polymer shielded adenovirus.

In the following, in order to confirm superior gene transfection efficiency of APC and PEI-2k in a CAR-ablate way,

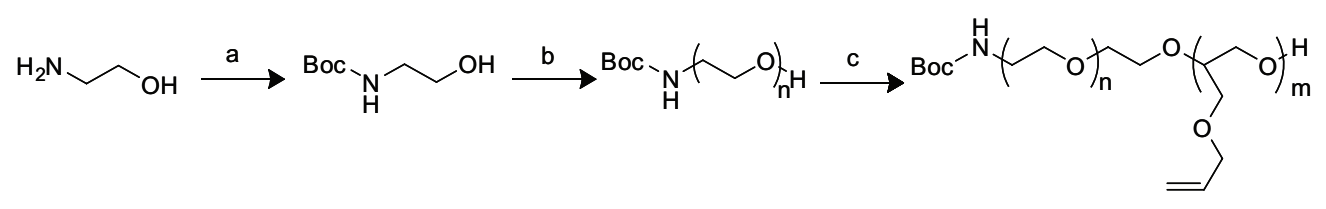

aminoethanol

Boc-aminoethanol Boc-amino-(EO) ${ }_{n}$

Boc-amino- $(E O)_{n}-(A G E)_{m}$

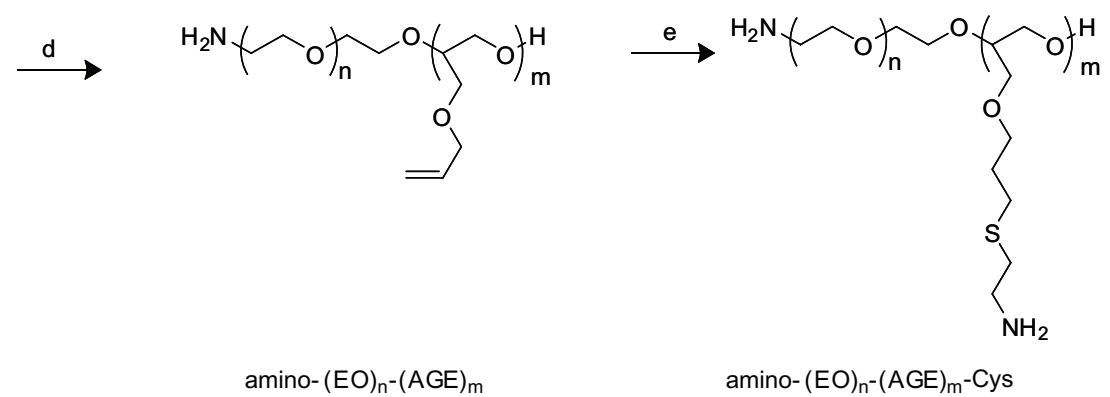

Figure 2 Synthesis scheme of APC. (a) (Boc) $2 \mathrm{O}, \mathrm{NaOH}, \mathrm{MeOH}: \mathrm{H}_{2} \mathrm{O}=\mathrm{I}: \mathrm{I}$ (v/v), RT, 12 hours. (b) $\mathrm{NaH}, \mathrm{EO}$, dioxane, $60^{\circ} \mathrm{C}, 4$ days. (c) $\mathrm{NaH}, \mathrm{AGE}, 60^{\circ} \mathrm{C}, 3$ days. (d) Trifluoroacetic acid:dichloromethane = I:4 (v/v), RT, 2 hours. (e) $\mathrm{MeOH}, \mathrm{RT}, 2$ days.

Abbreviations: APC, cationic PEG derivative; EO, ethylene oxide; AGE, allyl glycidyl ether; RT, room temperature. 


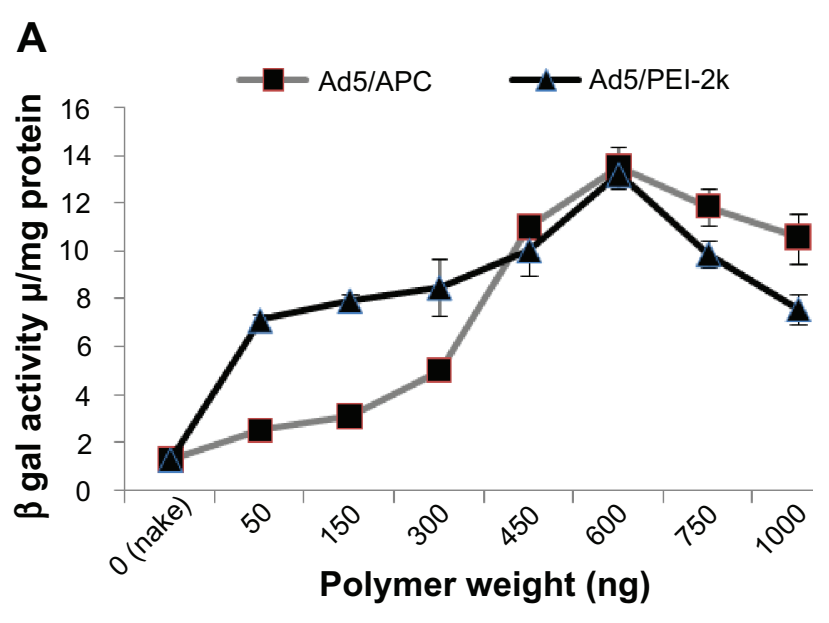

B

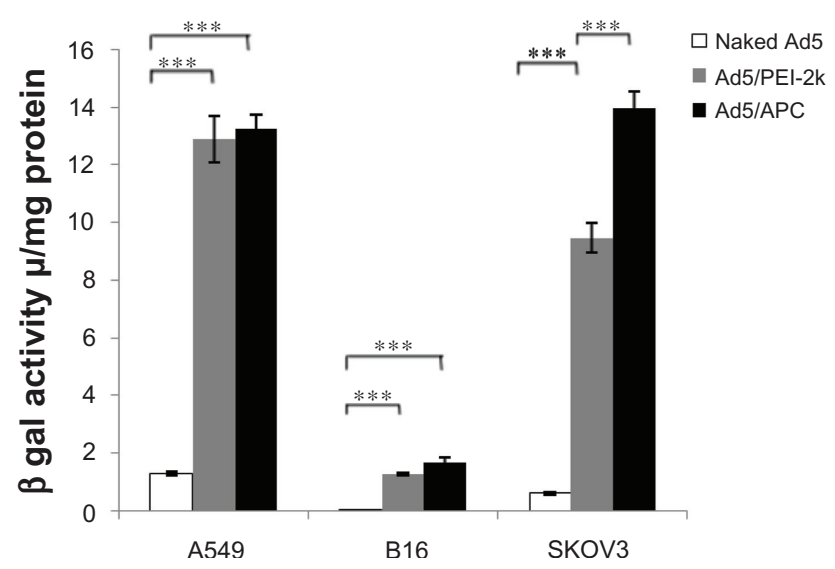

Figure 3 In vitro transfection assays of Ad5 or complexes. To determine the best ratio of $A d 5$ and polymers, transfection assays were performed in A549 cells treated with Ad5-LacZ (I.25 $\times 10^{7} \mathrm{pfu} /$ well) complexed with a serial dose of polymers, PEI-2k or APC (50 1000 ng). Following incubation for 24 hours after transfection, the cells was lyzed for quantity of $\beta$-galactosidae (A). Transfection assays in A549, B 16, and SKOV3 treated with Ad5 alone (I.25 $\times 10^{7}$ pfu/well) or complexes (Ad5/PEl-2k or Ad5/APC) at the optimal ratio (B).

Notes: Data are represented as mean $\pm S D(n=3)$, $* * * P<0.001$.

Abbreviations: Ad5, adenovirus vectors type 5; APC, cationic PEG derivative; PEI, polyethylenimine; Ad5/APC, adenovirus complexed with APC; Ad5/PEl-2k, adenovirus complexed with PEI-2k; pfu, plaque forming units; SD, standard deviation.

in vitro transfection assays of the complexes at the optimal ratio were performed as above in CAR-negative SKOV3 and B16 cells. As represented in Figure 3B, naked Ad5 showed far lower expression of $\beta$-gal in B16 cells and SKOV3 cells than in A549 cells. Greatly increased expression of $\beta$-gal was observed for Ad5 complexed with APC or PEI-2k. The gene expression efficiency of Ad5 was improved about 40 times in B16 cells and about 23 times in SKOV3 cells by the complexation with APC. Interestingly, there was no significant difference between APC and PEI-2k for Ad5-mediated gene therapy in A549 or B16 cells. While in SKOV3 cells, APC exhibited significantly higher gene expression than PEI-2k
Table I Zeta potential and size distribution of naked Ad5 and complexes $^{\mathrm{a}}$

\begin{tabular}{lccc}
\hline & $\begin{array}{l}\text { Zeta potential } \\
(\mathbf{m V})\end{array}$ & Size $(\mathbf{n m})$ & \multicolumn{1}{l}{ PDI } \\
\hline Naked Ad5 & $-17.56 \pm 0.53$ & $115.6 \pm 5.46$ & $0.04 \pm 0.037$ \\
Ad5/PEI-2k & $9.64 \pm 0.67$ & $1382 \pm 79.9$ & $0.084 \pm 0.1 \mathrm{I}$ \\
Ad5/APC & $31.23 \pm 0.4$ & $130.2 \pm 0.60$ & $0.02 \pm 0.01$ \\
\hline
\end{tabular}

Notes: ${ }^{a}$ Complexes were respectively prepared at optimal ratio. Values are represent as mean $\pm S D, n=3$.

Abbreviations: Ad5, adenovirus vectors type 5; PDI, polydispersity index; PEI, polyethylenimine; APC, cationic PEG derivative; Ad5/APC, adenovirus complexed with APC; Ad5/PEI-2k, adenovirus complexed with PEI-2k; SD, standard deviation.

$(P<0.001)$. The results further confirmed that Ad5 with cationic polymers modification enabled improved gene expression in CAR-positive or negative cells. As expected, APC can achieve as efficient transduction as commercial PEI-2k.

\section{Investigation of physical properties and morphology of Ad5 alone or complexes}

Particle sizes and surface potential of naked adenovirus or complexes (Ad5/PEI-2k, Ad5/APC) at the optimal ratio were measured by dynamic light scattering and electrophoretic light scattering respectively. As shown in Table 1, the surface potential of the complexes turned positive, $9.64 \pm 0.67 \mathrm{mV}$ for Ad5/ PEI-2k and $31.23 \pm 0.40 \mathrm{mV}$ for Ad5/APC while naked Ad5 remained negatively charged, $-17.56 \pm 0.53 \mathrm{mV}$. This result suggested that the copolymers had been ionically anchored on the viral surface, forming newly cationic hybrid vectors. Compared with naked Ad5 (115.6 $\pm 5.46 \mathrm{~nm}), \operatorname{Ad} 5 / \mathrm{APC}(130.2 \pm 0.60 \mathrm{~nm})$ had a slightly increased particle diameter. But the particle diameter of Ad5/PEI-2k was over 1 micrometer $(1382 \pm 79.9 \mathrm{~nm})$ suggesting a severe aggregation induced by PEI-2k. Low polydispersity index value indicated all formulations had uniform distribution. The study demonstrated that APC and PEI-2k were accessible to complex with adenovirus by ionic interaction. Moreover, APC modification makes adenovirus relatively stable to commercial PEI-2k, which may facilitate gene delivery in vivo. Figure 4 showed the morphology of naked Ad5 or APCcoated Ad5 complex at an optimal ratio by TEM. Both naked Ad5 and Ad5/APC complex showed regular morphology with uniform distribution. But compared to Ad5 alone, Ad5/APC complex exhibited a notable shell-core structure. This result indicated that APC polymer had been ionically anchored onto the surface protein of Ad5, forming a coated Ad5.

\section{Cytotoxicity}

Cytotoxicity of adenovirus coated with a serial concentration of APC, PEI-2k, or PEI-25k $(1,5,10,20 \mu \mathrm{g} / \mathrm{mL})$ were determined on A549, SKOV3, and B16 cells, using MTT 

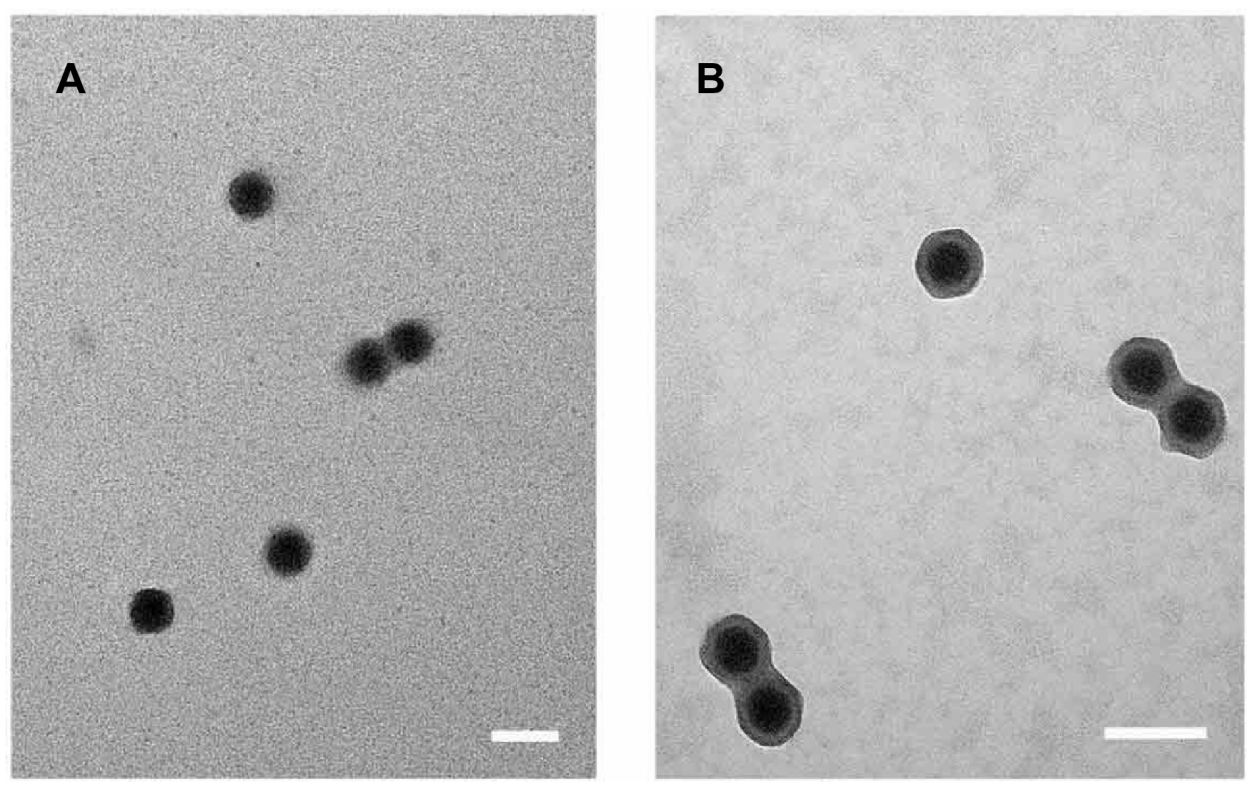

Figure 4 Transmission electron microscopy images of the naked adenovirus (A) and adenovirus complexed with APC (B).

Note: Arrow bar $=100 \mathrm{~nm}$.

Abbreviation: APC, cationic PEG derivative.

assay. As shown in Figure 5, the cytotoxicity of PEI-25k was concentration-dependent in the three cell lines. Ad5 complexed with a low concentration of PEI- $25 \mathrm{k}(1 \mu \mathrm{g} / \mathrm{mL})$ showed little cytotoxicity while the cell viability decreased along with the increased concentration of PEI-25k. When the concentration of PEI- $25 \mathrm{k}$ rose to $20 \mu \mathrm{g} / \mathrm{mL}$, the relative cell viability decreased to $30.3 \% \pm 3.66 \%$ for A 549 cells, $22.0 \% \pm 2.62 \%$ for B16 cells, and $34.8 \% \pm 6.90 \%$ for SKOV3 cells. However, over the range of designed concentration $(1 \mu \mathrm{g} / \mathrm{mL}$ $\sim 20 \mu \mathrm{g} / \mathrm{mL}$ ), there was no significant difference between APC and PEI-2k $(P>0.05)$, both of which exhibited no cytotoxicity to the three cell lines. The result demonstrated that the aminated PEG derivative (APC), as well as low MW PEI-2k, was a relatively safe polymer to PEI-25k, giving APC potential for further study in vitro or in vivo.

\section{In vitro neutralizing assays}

To evaluate the ability of Ad5 complexed with APC evading anti-Ad5 neutralizing antibody, naked Ad5, Ad5/APC, or Ad5/PEI-2k complexes were respectively incubated at $37^{\circ} \mathrm{C}$ for 1 hour with blank serum or antiserum isolated from immunized mice or nonimmunized mice. The incubated mixtures were then treated with A549 cells for transfection assays. As shown in Figure 6 , for the three samples treated with blank serum, there were no significant differences between 1:50 dilution and 1:250 dilution. Wherein, Ad5/APC complex achieved gene transduction as efficient as Ad5/PEI-2k, significantly more efficient than naked Ad5. The result almost matched in vitro transfection assays in Figure 3A. When the samples were exposed to antiserum at the dilution 1:250, the gene transfection efficiency of naked Ad5 decreased by about 7.1 times, from $1.18 \pm 0.014 \mathrm{u} / \mathrm{mg}$ to $0.17 \pm 0.02 \mathrm{u} / \mathrm{mg}$, revealing that anti-Ad5 neutralizing antibody had been successfully generated by intramuscular administration in mice. Comparatively, at the same dilution, Ad5/PEI-2k showed a decrease by 5.4 times, from $6.44 \pm 0.056 \mathrm{u} / \mathrm{mg}$ to $1.19 \pm 0.016 \mathrm{u} / \mathrm{mg}$, which was still a higher transduction than naked Ad5. At the 1:50 dilution of antiserum, PEI-2k-mediate gene expression almost decreased to the same level as naked Ad5, while Ad5/APC still exhibited significantly efficient gene transfer. Compared with Ad5/APC at the 1:50 dilution of antiserum, there was just a 2.4 times decrease from $5.70 \pm 0.13 \mathrm{u} / \mathrm{mg}$ to $2.28 \pm 0.32 \mathrm{u} / \mathrm{mg}$. Furthermore, no significant difference was found for Ad5/APC exposed to $1: 50$ versus $1: 250$ diluted antiserum. The above results revealed that, (1) immunized serum containing NAb against Ad5 could inactive naked Ad5 in a titer-related way; (2) PEI-2k could partially protect Ad5 evading NAb with a low titer relative to Ad5 alone; and, most importantly, (3) APC was significantly better at allowing Ad5 to escape from NAb than PEI-2k, which may be due to the effect of PEG being present on the APC polymer. 


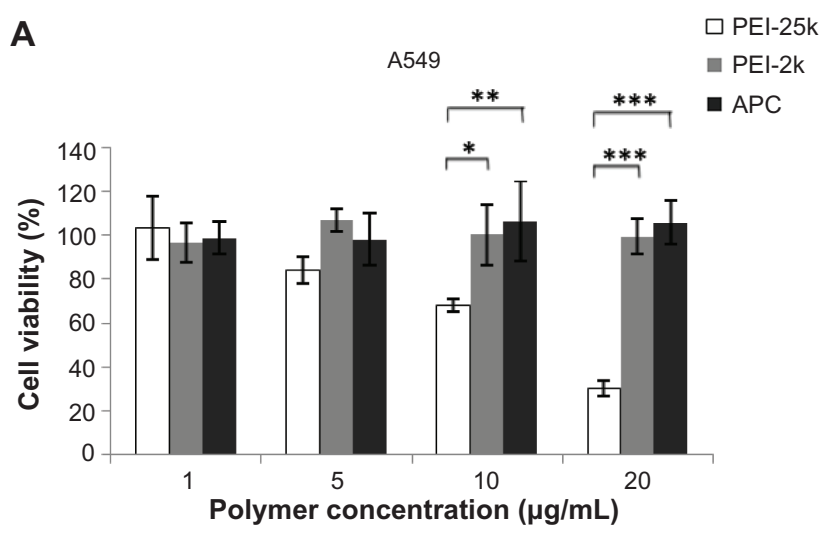

B

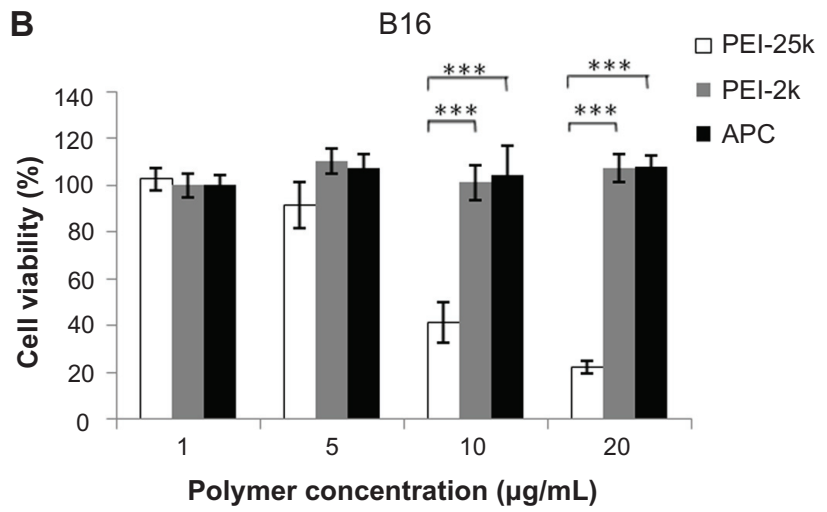

C

SKOV3

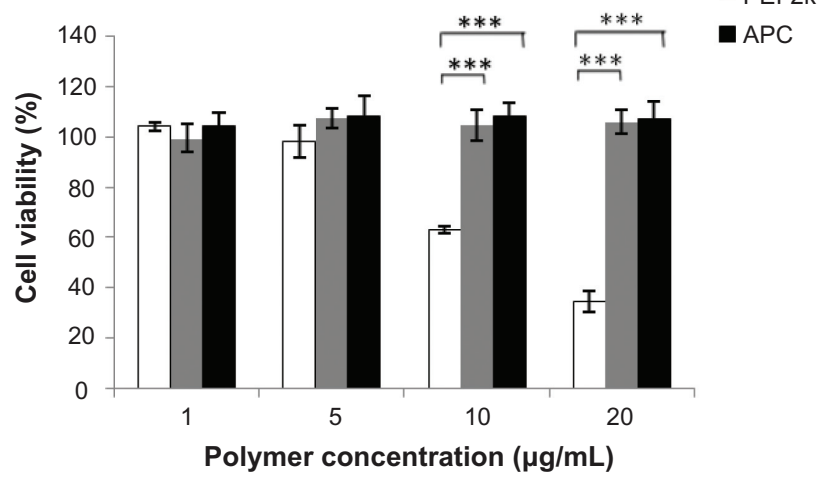

Figure 5 Relative viability of (A) A549, (B) BI6, and (C) SKOV3 cells treated with Ad5 (I.25 $\times 10^{6} \mathrm{pfu} /$ well) complexed with a serial concentration of APC, PEI-25k, and PEI-2k over the range from I $\mu \mathrm{g} / \mathrm{mL}$ to $20 \mu \mathrm{g} / \mathrm{mL}$. Each sample has five repeated wells.

Notes: Data are represented as mean \pm SD $(\mathrm{n}=5)$, *P $<0.05, * * P<0.01$, $* * * P<0.001$.

Abbreviations: Ad5, adenovirus vectors type 5; pfu, plaque forming units; PEI, polyethylenimine; APC, cationic PEG derivative; SD, standard devation.

\section{Discussion}

To construct a safe and efficient Adv-based vector system which is robust in the presence of NAb and permits repeated administration in clinical trials, a number of polymers have been extensively investigated to incorporate onto the surface of adenovirus. Thus, a shielded vector was formed to prevent Adv from interaction with proteins or cells in blood, induce low immune response, and facilitate Adv evading $\mathrm{Nab}^{39-42}$ In our study, the cationic PEG derivative (APC), a linear PEG with one side blocked by amines, was designed to modify the surface protein of Ad5 by physical adsorption. The complex (Ad5/APC) with PEG extending outside achieved a satisfiable protection of Adv from NAb as well as highly enhanced gene expression efficiency.

Prior to the synthesis of APC, the size of PEG and the number of amine pendants had been taken into serious consideration. In general, 3 5k MW of PEG were frequently used to form a compact coating. But recently, some reports revealed that the size and density of PEG anchored on to the surface protein of adenovirus played a crucial part in the biodistribution in vivo. ${ }^{25,43,44}$ Large size of PEG $(20 \mathrm{kd})$ not small size (3-5 kd) remarkably facilitated detargeting from liver thus relatively reduced hepatotoxicity and made systemic administration of adenovirus possible as well as allowing evasion from NAb. Therefore, APC (approximately $20 \mathrm{kd}$ ) with linear PEG (approximately $13 \mathrm{kd}$ ) was synthesized in the current study. Meanwhile, the number of primary amines mounting on one side of APC, which was closely related to the density of APC anchored onto Ad5, was evaluated as 36 according to GPC and elementary analysis. Branched PEI-2k contains a total of about 50 amines, of which primary amines account for $25 \%$ and secondary amines $50 \%$. Comparatively, APC may bear more positive charge than PEI-2k. Additionally, we had tried to reduce the number of amines by a third via a lower AGE mole ratio, but weaker protection ability from NAb was obtained (data not shown). The optimal number of amines requires further study.

In the past, cationic polymers have been explored to carry plasmid or viruses for gene delivery, with achievement of improved gene transduction. One explanation for the enhanced effect was that positively charged complexes (Adv/polymers) facilitated interaction with negatively charged cells. At a starting point to select a control to APC in our study, PEI-600, PEI$2 \mathrm{k}$, and PEI-25k were respectively complexed with Ad5 at the optimal ratio then applied to A549 cells. We found there was no significant difference between PEI-25k and naked Ad5 for Adv-based gene expression. Interestingly, PEI-2k was far superior to PEI-600 or PEI-25k, and had 10 times enhanced gene expression than naked Ad5 (data not shown). Commercially branched PEI-25k as one of the most efficient polymers in gene transduction, was usually used as a benchmark to other biomaterials especially newly synthesized polymers for carrying gene delivery. ${ }^{45,46}$ Similarly, authors have shown that PEI-25k exhibited somewhat lower gene expression of Adv than naked 


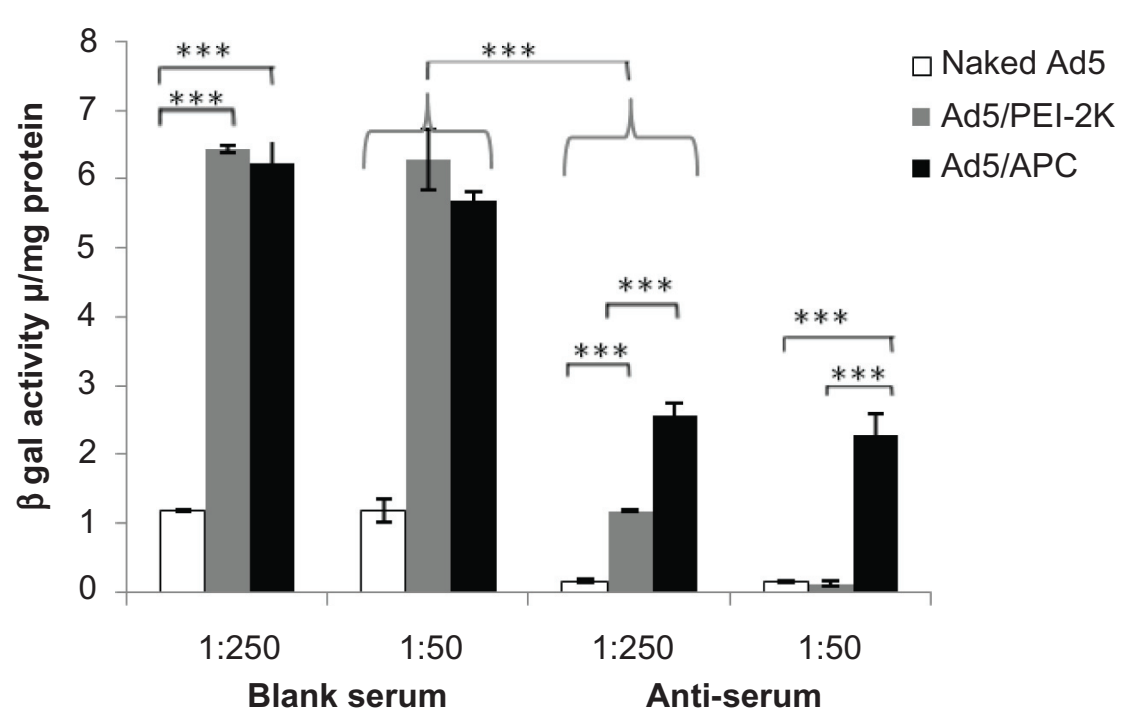

Figure 6 Neutralizing assays in A549 cells treated with Ad5 alone ( $1.25 \times 10^{7}$ pfu), Ad5/PEI-2k or Ad5/APC at the optimal ratio. Before transfection, a neutralizing effect was processed by incubation of naked Ad5 or freshly prepared complexes (Ad5/PEl-2k or Ad5/APC) and complement-inactivated blank serum or antiserum which respectively isolated from nonimmunized or immunized $\mathrm{C} 57 \mathrm{BL} / 6 \mathrm{~N}$ mice at $37^{\circ} \mathrm{C}$ for I hour. The following processes were performed as described in in vitro transfection assays. Notes: Data are represented as mean $\pm S D(n=3)$, *** $P<0.001$.

Abbreviations: Ad5, adenovirus vectors type 5; PEl, polyethylenimine; APC, cationic PEG derivative; pfu, plaque forming units; Ad5/PEl-2k, adenovirus complexed with PEl-2k; Ad5/APC, adenovirus complexed with APC; SD, standard deviation.

Adv in A549 cells and C2C12 cells. ${ }^{45}$ A recent report indicated that PEI-25k significantly enhanced Adv uptake but had no effect on transgenic expression, compared to naked $\mathrm{Adv} .{ }^{47}$ Normally, Adv-mediated gene delivery begins with binding and internalization into cells. During endocytosis, fibers are detached. Afterwards, hexons, pentons, and other structural proteins are dissociated, resulting in Adv escaping from endosome into cytosol and subsequent import to nucleus via interaction with cytoplasmic dynein. ${ }^{22,48}$ Each step may influence a successful delivery. Since PEI-25k facilitates Adv internalization but not transgenic expression, this suggests that PEI-25k bears more positive charge, affording a strong electrostatic force for Adv/PEI-25k complex and a difficult release for Adv from the polymer. Comparatively, PEI-2k may mediate a better Adv gene delivery among the PEI polymers.

In our study, PEI-2k showed 10 times more efficient gene expression than naked Adv in A549 cells. To the best of our knowledge, the enhanced transduction of Adv mediated by PEI-2k has not been reported previously. In our study, Ad5/ APC complex enhanced Ad5-mediated gene transfer to the same extent as PEI-2k in CAR-positive cells (A549) or CAR-negative cells (B16), and interestingly, significantly more greatly than PEI-2k in CAR-deficient cells (SKOV3). The significant difference of gene expression between Ad5/ PEI-2k and Ad5/APC in SKOV3 needs further exploration. The observed enhanced gene expression by APC was meaningful: (1) It makes lower doses of Adv available
- higher doses of Adv induce a severe immunoresponse and hepatotoxicity. ${ }^{49}$ (2) Adv infect cells mainly via CARdependent endocytosis, ${ }^{50,51}$ leaving a limit to be internalized by CAR-poor tumor cells. Polymer coatings gifted Adv with CAR-ablated infection ability for nonspecific cell uptake. ${ }^{52}$ (3) A ligand can be added to retarget for in vivo study and prevent unwanted binding of Ad5 to human erythrocytes which were found to be present in CAR. ${ }^{53}$

The physical property of Ad5 alone or Ad5/APC complex was characterized by measurements of particle size and zeta potential. Ad5/PEI-2k complex had an average diameter of $1382 \pm 79.9 \mathrm{~nm}$. The result was in agreement with previous reports that cationic polymers without exception induced severe aggregation of viral vectors. ${ }^{27}$ The aggregation enabled a greater contact of adenovirus to cell monolayer, which was another mechanism proposed for enhanced gene transduction by cationic polymers. ${ }^{52,54}$ But complexes up to 1 micrometer in size may afford poor permeability into tumor vessels where the maximum diameter size of $400 \sim 600 \mathrm{~nm}$ was required. ${ }^{55}$ The unstable complex may potentially interact with negatively charged protein or cells, inducing immediate cytotoxicity. While APC makes a stable hybrid vector, $130.2 \pm 0.60 \mathrm{~nm}$ is a slightly increased diameter than adenovirus alone. Ad5/APC complexes with such a size may benefit from enhanced permeability and retention effect when applied in vivo for cancer treatment. ${ }^{56}$ The TEM image of Ad5/APC supported that Ad5/ APC complexes have been formed in shell core structure. 
Furthermore, cytotoxicity is the bottleneck for cationic polymers such as PEI to be utilized in clinics. The polymer cytotoxicity is closely related to factors such as MW, concentration of free cationic polymers, ionic strength, and the processes after entry into cells. ${ }^{39,57}$ For plasmids, gene expression efficiency is in proportion to polymeric size. High gene expression efficiency needs a large size but is accompanied by severe cytotoxicity. Furthermore, in vivo studies require highly increased doses of complex, thus the release of nonbiodegradable polymer from the complex after entry into cells is a nondesirable side effect. To reduce cytotoxicity, biodegradable biomaterials have been widely investigated. Another effective strategy is the introduction of PEG into cationic polymers. As reported, PEG can prevent cationic complexes from interaction with other proteins, thus stabilizing the complex and reducing cytotoxicity. ${ }^{58,59}$ For example, it was demonstrated that PLL $(24 \mathrm{kd})$ showed cytotoxicity to KB cells from 1 $\mu \mathrm{g} / \mathrm{mL}$, but PLL (24 kd) with a PEG grafting ratio of $8.4 \%$ (PLL-g-PEG) showed little cytotoxicity over the range of 1 $\mu \mathrm{g} / \mathrm{mL}$ to $10 \mu \mathrm{g} / \mathrm{mL} .{ }^{59}$ The low cytotoxity of APC in our study warrants further investigation of the complex.

Although APC enabled a stable, low toxic Ad5-mediated system with high gene transduction efficiency, Ad5-mediated gene therapy has also been hindered by the neutralization of NAb towards Adv, making readministration problematic. Shielding antigen epitope of Adv and avoidance of recognition by NAb are anticipated. Therefore, it is key to develop a stable and robust Adv-shielded vector before endocytosis into cells. In the present study, APC-based protection ability of Ad5 from NAb was evaluated. The results indicated that commercial PEI-2k offered weak protection of Ad5 from NAb. But the Ad5/APC complex showed relatively good resistance to NAb. This superior protection effect was mainly contributed by the PEG segments present on APC. The unstable Ad5/PEI-2k complex may be more susceptible to NAb or other negatively charged proteins in serum than the Ad5/APC complex. In addition, polymer coating by physical adsorption permitted a systemic administration by reducing hepatic uptake and extending blood half-life. ${ }^{41,60}$ Therefore, APC may be a potential Adv-carrier for gene therapy.

Taken together, we present a novel polymer-coated Adv delivery system, which is simple, stable, has low toxicity, and is highly efficient in transgenic expression. More importantly, this system offered good protection of Adv from NAb in vitro. This Adv delivery system is based on a newly designed cationic PEG derivative. If necessary, PEG length and amines pendants or positive charge present on the copolymer can be easily optimized by adjusting the molar ratio among
Boc-aminoethanol, EO, and AGE. Meanwhile, the amines of the copolymer afford many conjunctive sites for the conjugation of ligands or active proteins, thus it is more susceptible to reconstruct a specifically desired copolymer. In future studies, we will investigate in vivo delivery of APC under the establishment of a pre-existing immunized animal model.

\section{Acknowledgments}

We are thankful for the financial support of the National Natural Science Foundation of China (No. 81173011) and Program for New Century Excellent Talents in University (No. NTEC-10-0601) and the National Science \& Technology Major Project of China (No. 2011ZX09401-304[4-3]) We also thank Miss Mengtian Zhang and Mr Sanjun Shi for their help with this study.

\section{Disclosure}

The authors report no conflicts of interest in this work.

\section{References}

1. Haisma HJ, Bellu AR. Pharmacological interventions for improving adenovirus usage in gene therapy. Mol Pharm. 2011;8(1):50-55.

2. Matthews QL. Capsid-incorporation of antigens into adenovirus capsid proteins for a vaccine approach. Mol Pharm. 2011;8(1):3-11.

3. Renteria SS, Clemens CC, Croyle MA. Development of a nasal adenovirus-based vaccine: Effect of concentration and formulation on adenovirus stability and infectious titer during actuation from two delivery devices. Vaccine. 2010;28(9):2137-2148.

4. Gene therapy clinical trials worldwide [database on the Internet]. J Gene Med.Available from: http://www.wiley.com//legacy/wileychi/genmed/ clinical/. Accessed January 25, 2011.

5. Horowitz J. Adenovirus-mediated p53 gene therapy: overview of preclinical studies and potential clinical applications. Curr Opin Mol Ther. 1999;1(4):500-509.

6. Ma G, Shimada H, Hiroshima K, Tada Y, Suzuki N, Tagawa M Gene medicine for cancer treatment: commercially available medicine and accumulated clinical data in China. Drug Des Devel Ther. 2009;2:115-122.

7. Singh R, Kostarelos K. Designer adenoviruses for nanomedicine and nanodiagnostics. Trends Biotechnol. 2009;27(4):220-229.

8. Wu TL, Ertl HC. Immune barriers to successful gene therapy. Trends Mol Med. 2009;15(1):32-39.

9. Zaiss AK, Machado HB, Herschman HR. The influence of innate and pre-existing immunity on adenovirus therapy. $J$ Cell Biochem. 2009;108(4):778-790.

10. Zhong Z, Han J, Wan Y, Zhang Z, Sun X. Anionic liposomes enhance and prolong adenovirus-mediated gene expression in airway epithelia in vitro and in vivo. Mol Pharm. 2011;8(3):673-682.

11. Sun C, Zhang Y, Feng L, et al. Epidemiology of adenovirus type 5 neutralizing antibodies in healthy people and AIDS patients in Guangzhou, southern China. Vaccine. 2011;29(22):3837-3841.

12. Mast TC, Kierstead L, Gupta SB, et al. International epidemiology of human pre-existing adenovirus (Ad) type-5, type-6, type-26 and type36 neutralizing antibodies: correlates of high Ad5 titers and implications for potential HIV vaccine trials. Vaccine. 2010; 28(4):950-957.

13. Pilankatta R, Chawla T, Khanna N, Swaminathan S. The prevalence of antibodies to adenovirus serotype 5 in an adult Indian population and implications for adenovirus vector vaccines. $J$ Med Virol. 2010;82(3):407-414. 
14. Singh R, Tian B, Kostarelos K. Artificial envelopment of nonenveloped viruses: enhancing adenovirus tumor targeting in vivo. FASEB J. 2008;22(9):3389-3402.

15. Eto Y, Yoshioka Y, Ishida T, et al. Optimized PEGylated adenovirus vector reduces the anti-vector humoral immune response against adenovirus and induces a therapeutic effect against metastatic lung cancer. Biol Pharm Bull. 2010;33(9):1540-1544.

16. Mok H, Palmer DJ, Ng P, Barry MA. Evaluation of polyethylene glycol modification of first-generation and helper-dependent adenoviral vectors to reduce innate immune responses. Mol Ther. 2005;11(1):66-79.

17. Eto Y, Gao JQ, Sekiguchi F, et al. Neutralizing antibody evasion ability of adenovirus vector induced by the bioconjugation of methoxypolyethylene glycol succinimidyl propionate (MPEG-SPA). Biol Pharm Bull. 2004;27(6):936-938.

18. Croyle MA, Chirmule N, Zhang Y, Wilson JM. "Stealth" adenoviruses blunt cell-mediated and humoral immune responses against the virus and allow for significant gene expression upon readministration in the lung. J Virol. 2001;75(10):4792-4801.

19. Kim PH, Sohn JH, Choi JW, et al. Active targeting and safety profile of PEG-modified adenovirus conjugated with herceptin. Biomaterials. 2011;32(9):2314-2326.

20. Lee GK, Maheshri N, Kaspar B, Schaffer DV. PEG conjugation moderately protects adeno-associated viral vectors against antibody neutralization. Biotechnol Bioeng. 2005;92(1):24-34.

21. O'Riordan CR, Lachapelle A, Delgado C, et al. PEGylation of adenovirus with retention of infectivity and protection from neutralizing antibody in vitro and in vivo. Hum Gene Ther. 1999;10(8):1349-1358.

22. Eto Y, Yoshioka Y, Mukai Y, Okada N, Nakagawa S. Development of PEGylated adenovirus vector with targeting ligand. Int J Pharm. 2008;354(1-2):3-8.

23. Jung Y, Park HJ, Kim PH, et al. Retargeting of adenoviral gene delivery via Herceptin-PEG-adenovirus conjugates to breast cancer cells. J Control Release. 2007;123(2):164-171.

24. Suzuki-Kouyama E, Katayama K, Sakurai F, et al. Hexon-specific PEGylated adenovirus vectors utilizing avidin-biotin interaction. Biomaterials. 2011;32(6):1724-1730.

25. Wortmann A, Vöhringer S, Engler T, et al. Fully detargeted polyethylene glycol-coated adenovirus vectors are potent genetic vaccines and escape from pre-existing anti-adenovirus antibodies. Mol Ther. 2008;16(1):154-162.

26. Wang IJ, Jhuang MC, Chen YH, Yeh LK, Liu CY, Young TH. Chitosan modification of adenovirus to modify transfection efficiency in bovine corneal epithelial cells. PLoS One. 2010;5(8):e12085.

27. Fasbender A, Zabner J, Chillón M, et al. Complexes of adenovirus with polycationic polymers and cationic lipids increase the efficiency of gene transfer in vitro and in vivo. J Biol Chem. 1997; 272(10):6479-6489.

28. Steel JC, Cavanagh HM, Burton MA, Dingwall DJ, Kalle WH. Modification of liposomal concentration in liposome/adenoviral complexes allows significant protection of adenoviral vectors from neutralising antibody, in vitro. J Virol Methods. 2005;126(1-2):31-36.

29. Dodds E, Piper TA, Murphy SJ, Dickson G. Cationic lipids and polymers are able to enhance adenoviral infection of cultured mouse myotubes. J Neurochem. 1999;72(5):2105-2112.

30. Moselhy J, Sarkar S, Chia MC, et al. Evaluation of copolymers of $\mathrm{N}$-isopropylacrylamide and 2-dimethyl(aminoethyl)methacrylate in nonviral and adenoviral vectors for gene delivery to nasopharyngeal carcinoma. Int J Nanomedicine. 2007;2(3):461-478.

31. Lv H, Zhang S, Wang B, Cui S, Yan J. Toxicity of cationic lipids and cationic polymers in gene delivery. J Control Release. 2006;114(1):100-109.

32. Ahn CH, Chae SY, Bae YH, Kim SW. Synthesis of biodegradable multi-block copolymers of poly(L-lysine) and poly(ethylene glycol) as a non-viral gene carrier. J Control Release. 2004;97(3): 567-574.

33. Liang B, He ML, Xiao ZP, et al. Synthesis and characterization of folatePEG-grafted-hyperbranched-PEI for tumor-targeted gene delivery. Biochem Biophys Res Commun. 2008;367(4):874-880.
34. Lai WF, Lin MC. Nucleic acid delivery with chitosan and its derivatives. J Control Release. 2009;134(3):158-168.

35. Eto Y, Gao JQ, Sekiguchi F, et al. PEGylated adenovirus vectors containing RGD peptides on the tip of PEG show high transduction efficiency and antibody evasion ability. J Gene Med. 2005;7(5):604-612.

36. Yamashita M, Ino A, Kawabata K, Sakurai F, Mizuguchi H. Expression of coxsackie and adenovirus receptor reduces the lung metastatic potential of murine tumor cells. Int J Cancer. 2007;121(8): 1690-1696.

37. Kim JS, Lee SH, Cho YS, Choi JJ, Kim YH, Lee JH. Enhancement of the adenoviral sensitivity of human ovarian cancer cells by transient expression of coxsackievirus and adenovirus receptor (CAR). Gynecol Oncol. 2002;85(2):260-265.

38. Koyama Y, Ito T, Matsumoto H, et al. Novel poly(ethylene glycol) derivatives with carboxylic acid pendant groups: synthesis and their protection and enhancing effect on non-viral gene transfection systems. J Biomater Sci Polym Ed. 2003;14(6):515-531.

39. Han S, Mahato RI, Sung YK, Kim SW. Development of biomaterials for gene therapy. Mol Ther. 2000;2(4):302-317.

40. Fisher KD, Seymour LW. HPMA copolymers for masking and retargeting of therapeutic viruses. Adv Drug Deliv Rev. 2010;62(2): 240-245.

41. Subr V, Kostka L, Selby-Milic T, et al. Coating of adenovirus type 5 with polymers containing quaternary amines prevents binding to blood components. J Control Release. 2009;135(2):152-158.

42. Hofherr SE, Mok H, Gushiken FC, Lopez JA, Barry MA. Polyethylene glycol modification of adenovirus reduces platelet activation, endothelial cell activation, and thrombocytopenia. Hum Gene Ther. 2007;18(9): 837-848.

43. Doronin K, Shashkova EV, May SM, Hofherr SE, Barry MA. Chemical modification with high molecular weight polyethylene glycol reduces transduction of hepatocytes and increases efficacy of intravenously delivered oncolytic adenovirus. Hum Gene Ther. 2009;20(9):975-988.

44. Hofherr SE, Shashkova EV, Weaver EA, Khare R, Barry MA. Modification of adenoviral vectors with polyethylene glycol modulates in vivo tissue tropism and gene expression. Mol Ther. 2008;16(7):1276-1282.

45. Kim P-H, Kim TI, Yockman JW, Kim SW, Yun CO. The effect of surface modification of adenovirus with an arginine-grafted bioreducible polymer on transduction efficiency and immunogenicity in cancer gene therapy. Biomaterials. 2010;31(7):1865-1874.

46. Han J, Zhao D, Zhong Z, Zhang Z, Gong T, Sun X. Combination of adenovirus and cross-linked low molecular weight PEI improves efficiency of gene transduction. Nanotechnology. 2010;21(10):105-106.

47. Kasman LM, Barua S, Lu P, Rege K, Voelkel-Johnson C. Polymerenhanced adenoviral transduction of CAR-negative bladder cancer cells. Mol Pharm. 2009;6(5):1612-1619.

48. Kelkar SA, Pfister KK, Crystal RG, Leopold PL. Cytoplasmic dynein mediates adenovirus binding to microtubules. J Virol. 2004;78(18):10122-10132.

49. Morral N, O’Neal WK, Rice K, et al. Lethal toxicity, severe endothelial injury, and a threshold effect with high doses of an adenoviral vector in baboons. Hum Gene Ther. 2002;13(1):143-154.

50. Medina-Kauwe, LK. Endocytosis of adenovirus and adenovirus capsid proteins. Adv Drug Deliv Rev. 2003;55(11):1485-1496.

51. Meier O, Greber UF. Adenovirus endocytosis. J Gene Med. 2004; 6 Suppl 1:S152-S163.

52. Davis HE, Morgan JR, Yarmush ML. Polybrene increases retrovirus gene transfer efficiency by enhancing receptor-independent virus adsorption on target cell membranes. Biophys Chem. 2002;97(2-3): 159-172.

53. Carlisle RC, Di Y, Cerny AM, et al. Human erythrocytes bind and inactivate type 5 adenovirus by presenting Coxsackie virus-adenovirus receptor and complement receptor 1. Blood. 2009;113(9):1909-1918.

54. Davis HE, Rosinski M, Morgan JR, Yarmush ML. Charged polymers modulate retrovirus transduction via membrane charge neutralization and virus aggregation. Biophys J. 2004;86(2):1234-1242. 
55. Yuan F, Dellian M, Fukumura D, et al. Vascular permeability in a human tumor xenograft: molecular size dependence and cutoff size. Cancer Res. 1995;55(17):3752-3756.

56. Fisher KD, Green NK, Hale A, Subr V, Ulbrich K, Seymour LW. Passive tumour targeting of polymer-coated adenovirus for cancer gene therapy. J Drug Target. 2007;15(7-8):546-551.

57. Godbey WT, Wu KK, Mikos AG. Poly(ethylenimine) and its role in gene delivery. J Control Release. 1999;60(2-3):149-160.

58. Weiss SI, Sieverling N, Niclasen M, et al. Uronic acids functionalized polyethyleneimine (PEI)-polyethyleneglycol (PEG)-graft-copolymers as novel synthetic gene carriers. Biomaterials. 2006;27(10):2302-2312.
59. Park JW, Mok H, Park TG. Physical adsorption of PEG grafted and blocked poly-L-lysine copolymers on adenovirus surface for enhanced gene transduction. J Control Release. 2010;142(2):238-244.

60. Green NK, Herbert CW, Hale SJ, et al. Extended plasma circulation time and decreased toxicity of polymer-coated adenovirus. Gene Ther. 2004;11(16):1256-1263.
International Journal of Nanomedicine

\section{Publish your work in this journal}

The International Journal of Nanomedicine is an international, peerreviewed journal focusing on the application of nanotechnology in diagnostics, therapeutics, and drug delivery systems throughout the biomedical field. This journal is indexed on PubMed Central, MedLine, CAS, SciSearch $®$, Current Contents $® /$ Clinical Medicine,

\section{Dovepress}

Journal Citation Reports/Science Edition, EMBase, Scopus and the Elsevier Bibliographic databases. The manuscript management system is completely online and includes a very quick and fair peer-review system, which is all easy to use. Visit http://www.dovepress.com/ testimonials.php to read real quotes from published authors.

Submit your manuscript here: http://www.dovepress.com/international-journal-of-nanomedicine-journal 